\title{
Artículo Original | Original Article Dynamic changes of the main active constituents in valerian rhizome and root (Valeriana amurensis Smir. ex Kom.) during different harvest periods
}

\author{
[Cambios dinámicos de los principales constituyentes activos del rizoma y raíz valeriana (Valeriana amurensis \\ Smir. Ex Kom.) durante diferentes períodos de cosecha]
}

\author{
Junkai Wu ${ }^{1}$, Jinhai Huo ${ }^{1,2}$, Dan Yu${ }^{1}$, Dayong $\operatorname{Leng}^{1} \&$ Xiaowei Du${ }^{1}$ \\ ${ }^{1}$ Key Laboratory of Chinese Materia Medica, Ministry of Education, Pharmaceutical College, \\ Heilongjiang University of Chinese Medicine, Harbin, China \\ ${ }^{2}$ Institute of Chinese Materia Medica, Heilongjiang Academy of Chinese Medicine Sciences, Harbin, China \\ Contactos | Contacts: Xiaowei DU - E-mail address: xiaoweidu@ hotmail.com
}

\begin{abstract}
Valeriana amurensis Smir. ex Kom. widely distributed in the northeast region of China and some region in Russia and Korea, and its underground parts (roots and rhizomes) being used to cure nervous system diseases such as insomnia. The active components including the essential oil and iridoids of underground parts were investigated in different harvest periods in order to evaluate the quality for the roots and rhizomes of $V$. amurensis. The content of the essential oil was obtained by hydrodistillation and bornyl acetate in the oil was quantitated by GC-EI. The iridoids, valepotriates were determined by potentiometric titration and the main component, valtrate was quantitated by HPLC-UV. The factors of biomass were considered in the determination of collection period. Statistical analysis of results showed that, the highest content of the essential oil per plant was $22.69 \mu \mathrm{l}$ in withering period and then $21.58 \mu \mathrm{l}$ in fruit ripening period, while the highest contents of bornyl acetate, valepotriates and valtrate per plant were $2.82 \mathrm{mg}, 31.90 \mathrm{mg}$ and $0.98 \mathrm{mg}$ in fruit ripening period separately. Fruit ripening period was decided as the best harvest period for the content of active constituents and output of drug, and it would provide scientific basis for the artificial cultivation of V.amurensis.
\end{abstract}

Keywords: Valeriana amurensis; the essential oil; Bornyl acetate; Valepotriates; Valtrate; The best harvest period.

Resumen: Valeriana amurensis Smir. ex Kom. Se distribuye ampliamente en la región noreste de China y en algunas regiones de Rusia y Corea, y sus partes subterráneas (raíces y rizomas) se utilizan para curar enfermedades del sistema nervioso como el insomnio. Se investigaron los componentes activos, incluidos el aceite esencial y los iridoides de las partes subterráneas de $V$. amurensis en diferentes períodos de cosecha para evaluar la calidad de las raíces y rizomas. El contenido del aceite esencial se obtuvo mediante hidrodestilación y el acetato de bornilo en el aceite se cuantificó por GC-EI. Los iridoides, valepotriatos se determinaron mediante valoración potenciométrica y el componente principal, el valtrato se cuantificó por HPLC-UV. Los factores de biomasa fueron considerados en la determinación del período de recolección. El análisis estadístico de los resultados mostró que el mayor contenido de aceite esencial por planta fue de 22,69 $\mu 1$ en el período de marchitación y luego de $21,58 \mu \mathrm{l}$ en el período de maduración de la fruta, mientras que el mayor contenido de acetato de bornilo, valepotriatos y valtrato por planta fue de $2.82 \mathrm{mg}, 31.90 \mathrm{mg}$ y $0,98 \mathrm{mg}$, respectivamente, en el período de maduración de la fruta por separado. Se definió el período de maduración de la fruta como el mejor período de cosecha para el contenido de constituyentes activos y la producción de droga, lo cual proporcionaría una base científica para el cultivo artificial de V. amurensis.

Palabras clave: Valeriana amurensis; Aceite esencial; Acetato de bornilo; Valepotriatos; Valtrato; Mejor período de cosecha. 


\section{INTRODUCTION}

Valeriana which contains about 250 species is an important genus of the family Valerianaceae. As orthodox sedative, the using history of Valeriana officinalis L. roots and rhizomes is more than one thousand years. Now the commercial valerian preparations which have been used for sedative, antidepressant, antianxiety, anticonvulsant, antimicrobial and antispasmodic purposes play an influential role on herbal medicine market in the west, but the exact composition was often not clear (Fuzzati et al., 1996; Taibi et al., 2007). Extracts of the roots of $V$. officinalis might improve sleep quality without producing side effects in many randomized, placebo-controlled trials (Bent et al., 2006).

The available evidence suggests that The active constituents for sedative pharmaceutical activity from $V$. officinalis, $V$. wallichii, $V$. sisymbriifolia and $V$. celtica, including essential oils, valepotriates, valerenic acid and derivative, were investigated in the past one hundred years (Stoll \& Seebeck, 1957; Thies, 1966; Bos et al., 1997a; Novak et al., 2000; Schumacher et al., 2002; Marder et al., 2003; Cecilia et al., 2009; Javidnia et al., 2010). Owing to containing a great quantity volatile constituents, the essential oils were usually analysed by capillary GC, GC-MS and other instruments (Gränicher et al., 1995; Bos et al., 1997b; Kovacevic et al., 2002; Sati \& Mathela, 2005; Safaralie et al., 2008). Fluorescence-microscopy followed by image analysis of entire root cross-sections $V$. officinalis, showed that the oil droplets displayed varying density gradients from the inner to the outer regions depending on genotype, root thickness and harvesting depth (Penzkofer et al., 2018). As unique constituent for sedative in the essential oils from underground parts of $V$. officinalis L. s.l. and several closely related taxa, valerenic acids had usually been determinated together with valepotriates (Bos et al., 1996; Gao \& Björk, 2000; Shohet et al., 2001). Valepotriates could be analysed using spectophotometry, titrimetry, TLC, GC, HPLC, MS, $\mathrm{CE}$ as well as p-SFC, and HPLC is the main method of choice today (Bos et al., 2002).

During the seasons 1989-1993, V. officinalis plants were investigated for their contents of essential oil, valerenic acid and derivatives, and valepotriates, the plants should be harvested in March when the contents of the valerenic acid derivatives were considered the best quality parameter for the drug
(Bos et al., 1993; Bos et al., 1998). In study of seasonal variation of enriched fraction of valepotriates and essential oil in $V$. jatamansi underground parts during 2001-2006, consequence indicated that November or January was the ideal time to harvest $V$. jatamansi for enriched fraction of valepotriates production, while May is appropriate harvesting time for production of essential oil in western Himalayan region in India (Singh et al., 2010). However, the best harvest period can't be fixed at different region owing to different growing periods.

As a member of Valeriana family, $V$. amurensis Smir. ex Kom. widely distributed in the northeast region of China, the Far East region of Russia, Korea etc., and its underground parts (roots and rhizomes) being used as a sedative and hypnic medicine in the locality widely more than one hundred years. The major active constituents were valepotriates, bornyl acetate, bornyl isovalerate, linalool, which have been used to treat insomnia (Huo et al., 2007). There was no valerenic acid in $V$. amurensis Smir. ex Kom. and no report on its collection period. In order to provide a quality standard for the plants, the active constituents in the roots and rhizomes of $V$. ameurensis would be investigated in different harvest periods. The contents of the essential oil would be quantified, bornyl acetate, valepotriates and valtrate would be analysed by GC-EI or HPLC-UV. Then the best harvest period would be identified at last.

\section{MATERIAL AND METHODS Chemicals and reagents}

Bornyl acetate was supplied by National Institute for the Control of Pharmaceutical and Biological Products. Naphthalene was supplied by Tianjin Guangfu Fine Chemical Research Institute. Mixing standard substances of valtrate and isovaltrate (1:3) were obtained from Department of Pharmaceutical Biology, University Centre for Pharmacy, Groningen Institute for Drug Studies (GIDS), University of Groningen.

Potassium hydrogen phthalate, sodium hydrate, hydrochloric acid, acetone, chloroform, methanol were all meet analytical reagent purchased from Beijing Yili Fine Chemical Company (Beijing, P. R. China). 


\section{Plant material}

Authenticated roots and rhizomes of $V$. amurensis Smir. ex Kom. were collected from Erhaofangzi forest farm (E126 63'363", N51 $\left.{ }^{\circ} 69^{\prime} 713^{\prime \prime}\right)$ in Huma county of Daxing'anling region in the Northeast of China, at an altitude of 300-500 m, according growth habit of $V$. amurensis Smir. ex Kom. Thirty plants in each different growing periods (germination period on $14^{\text {th }}$ May, stooling period on $4^{\text {th }}$ June, flowering period on $27^{\text {th }}$ June, fruit ripening period on $1^{\text {th }}$ August and withering period on $10^{\text {th }}$ September) were collected. Voucher specimens (Herbarium No. 200708-200712) had been deposited in the Herbarium collection of the Pharmacognosy Laboratory, College of Pharmacy, Heilongjiang University of Chinese Medicine, China.

\section{Seasonal variation of dry weight, dry weight ratio and active constituents per plant}

The roots and rhizomes of thirty valerian plants per harvest period were selected and divided into three groups at random, ten plants per group. Samples were washed by hand and removed water on surface, then took down fresh weight. After be dried in the shade, dry weight of different the roots and rhizomes of valerian plant was got. The quanlity of the essential oil, the content of bornyl acetate in the essential oil, valepotriates and valtrate per plant were determined as mentioned before.

\section{Essential oil extraction}

The roots and rhizomes of different harvest period valerian plants were washed by hand and dried in the shade. The dried crude drug was ground to the particle size through a standard mesh sieve No. 2 and divided into three groups at random, $50 \mathrm{~g}$ per group. Each essential oil sample was isolated by hydrodistillation for $6 \mathrm{~h}$ in $600 \mathrm{ml}$ water after $2 \mathrm{~h}$ soak, using the apparatus described in the appendix $\mathrm{X}$ D 2005 edition Chinese Pharmacopeia. The oil samples were dried by anhydrous sodium sulphate and measured precisely, then stored at $-20^{\circ} \mathrm{C}$ until analysed.

\section{GC analysis of bornyl acetate}

The concentration of bornyl acetate was prepared to $2.19 \mathrm{mg} / \mathrm{ml}$ and the internal standard substance, naphthalene was diluted to $2.01 \mathrm{mg} / \mathrm{ml}$ both with methanol. The samples contained $0.1 \mathrm{ml}$ essential oil, $5 \mathrm{ml}$ internal standard solution and were kept volume to $25 \mathrm{ml}$.

GC analysis was performed on a Shimadzu QP5050A GC-MS equipped with a Class-5000 Chemstation, under the following conditions: Agilent DB-17 capillary column $(30 \mathrm{~m} \times 0.25 \mathrm{~mm}$ i.d.; film thickness $0.25 \mu \mathrm{m}$ ); oven temperature programme, 80 (remain 2 minutes) to $150^{\circ} \mathrm{C}$ (remain 3 minutes), then rise to $220^{\circ} \mathrm{C}$ at $3^{\circ} \mathrm{C} / \mathrm{min}$ and remain 25 minutes); injector temperature, $180^{\circ} \mathrm{C}$; detector (EI) temperature, $250^{\circ} \mathrm{C}$; carrier gas, helium; split ratio, 1:20; injected volume, $1.0 \mu \mathrm{l}$.

\section{Study on variation of valepotriates}

Mixing standard substances of valtrate and isovaltrate were measured $21.5 \mathrm{mg}$ and metered volume to $5 \mathrm{ml}$ with methanol precisely, then stored at $-20^{\circ} \mathrm{C}$ until analysed. Volumetric solution of sodium hydrate and hydrochloric acid were prepared to concentration at $0.01 \mathrm{M}$ respectively described in the appendix XV 2005 edition Chinese Pharmacopeia. Finely drug powder $(5 \mathrm{~g})$ was extracted with chloroform $(30 \mathrm{ml})$ in an ultrasonic bath for $60 \mathrm{~min}$, the resulting extract was filtered and the residue re-extracted twice with chloroform $(30 \mathrm{ml})$ using the same procedure except extracting time for $30 \mathrm{~min}$. Filtrate was put together and metered volume to $100 \mathrm{ml}$ with chloroform as sample solution. Sample solution $(10 \mathrm{ml})$ was evaporated to dryness under vacuum and redissolved in acetone $(30 \mathrm{ml})$, then $0.01 \mathrm{M}$ volumetric solution of sodium hydrate $(15 \mathrm{ml})$ was added and hydrolyzed in water bath (between 56 and $59^{\circ} \mathrm{C}$ ) for 30 minutes. Sample solution was titrated by $0.01 \mathrm{M}$ volumetric solution of hydrochloric acid, end point of titration was made sure described in the appendix VIII 2005 edition Chinese Pharmacopeia.

\section{HPLC analysis of valtrate}

The standard substance of mixing standard substances (valtrate and isovaltrate) were prepared to solution of concentration at $0.1030 \mathrm{mg} / \mathrm{ml}$, then stored at $-20{ }^{\circ} \mathrm{C}$ until analysed. Fine drug powder (1 g) was extracted with $10 \mathrm{ml}$ methanol in an ultrasonic bath for $40 \mathrm{~min}$, the resulting extract was filtered and the residue re-extracted twice with methanol $(10 \mathrm{ml}$, $5 \mathrm{ml})$ using the same procedure. All Filtrate was metered volume to $25 \mathrm{ml}$ with methanol and filtered by $0.45 \mu \mathrm{m}$ filter membrane as sample solution. Analyses were carried out on a Shimadzu LC-2010A HPLC equipped with a CLASS-VP chromatographic workstation. Column: Diamonsil C18 $(5 \mu \mathrm{m}, 250$ 
mm, ID 4.6 mm, Dikma), precolumn Hypersil C18 (5 $\mu \mathrm{m}, 20 \mathrm{~mm}$, ID $4.6 \mathrm{~mm}$ ), at $35^{\circ} \mathrm{C}$. Flowrate: $1 \mathrm{ml} / \mathrm{min}$. The mobile phase was a gradient elution of Methanol (A) and $0.5 \%$ aqueous phosphoric acid, commencing with $60 \% \mathrm{~A}$, rising to $70 \% \mathrm{~A}$ after $5 \mathrm{~min}$ then to $82 \%$ A after $22 \mathrm{~min}$, keep isogradient $82 \%$ A to $30 \mathrm{~min}$ and $90 \% \mathrm{~A}$ after $35 \mathrm{~min}$. The flow rate was $1 \mathrm{ml} / \mathrm{min}$, the detection wavelength was set at $255 \mathrm{~nm}$, the injection volume was $20 \mu \mathrm{l}$.

\section{Statistical analysis}

Statistical analysis was performed using Statistical Analysis System (SAS) software 917 SAS Institute Cay N.C. (USA). All Data were analyzed by one-way or two-way ANOVA tests and expressed as mean \pm standard deviation (S.D.). Analysis of variance using the PROC GLM procedure were performed to determine the contents of active substances, including the essential oil, bornyl acetate, valepotriates, valtrate, and dry weight, dry weight ratio during different harvest periods. A $P$ value of less than 0.05 was considered as statistically significant.

\section{RESULTS AND DISCUSSION}

Seasonal variation of the essential oil and bornyl acetate

With the growth of plants, the content of the essential oil decreased gradually from $31.05 \mu \mathrm{l} / \mathrm{g}$ in germination period to $20.61 \mu \mathrm{l} / \mathrm{g}$ in withering period (Table No. 1). Among of all harvest periods, the content of the essential oil in fruit ripening period was the lowest, $19.10 \mu \mathrm{l} / \mathrm{g}$. Contrary to it, maximum essential oil content in the underground parts of $V$. officinalis was reported in September month (Bos et al., 1998).

As the important volatile constituent in $V$. amurensis, the dynamic tendency of bornyl acetate was very extraordinarily similar to the essential oil. The highest content of bornyl acetate is $3.84 \mathrm{mg} / \mathrm{g}$ in germination period, while it was merely half of the former, $2.15 \mathrm{mg} / \mathrm{g}$ in withering period (Figure No. 1). However, essential oil yield was lowest in withering period followed by that in fruit ripening period. So, the contents of the essential oil and bornyl acetate change constantly with the increase of biomass during different growing periods.

Table No. 1

Determination of essential oil, bornyl acetate, valepotriates and valtrate content in rhizomes and roots of Valeriana amurensis in different harvest periods

\begin{tabular}{ccccc}
\hline Harvest time & $\begin{array}{c}\text { essential oil } \\
(\mu \mathrm{l} / \mathrm{g})\end{array}$ & $\begin{array}{c}\text { bornyl acetate } \\
(\mathrm{mg} / \mathrm{g})\end{array}$ & $\begin{array}{c}\text { valepotriates } \\
(\mathrm{mg} / \mathrm{g})\end{array}$ & $\begin{array}{c}\text { valtrate } \\
(\mathrm{mg} / \mathrm{g})\end{array}$ \\
\hline $\begin{array}{c}\text { Germination } \\
\text { period }\end{array}$ & $31.05^{\mathrm{a}}$ & $3.84^{\mathrm{a}}$ & $21.12^{\mathrm{c}}$ & $0.65^{\mathrm{b}}$ \\
$\begin{array}{c}\text { Stooling period } \\
\text { Flowering period }\end{array}$ & $27.23^{\mathrm{b}}$ & $3.25^{\mathrm{b}}$ & $27.37^{\mathrm{b}}$ & $0.80^{\mathrm{a}}$ \\
Fruit ripening & $21.86^{\mathrm{c}}$ & $2.72^{\mathrm{c}}$ & $14.23^{\mathrm{d}}$ & $\mathbf{0 . 3 1}^{\mathrm{c}}$ \\
$\begin{array}{c}\text { period } \\
\text { Withering period }\end{array}$ & $\mathbf{1 9 . 1 0}^{\mathrm{d}}$ & $2.64^{\mathrm{c}}$ & $28.23^{\mathrm{a}}$ & $0.87^{\mathrm{a}}$ \\
Variability & $* * *$ & $2.15^{\mathrm{d}}$ & $20.89^{\mathrm{c}}$ & $0.67^{\mathrm{b}}$ \\
LSD & $\pm \mathbf{0 . 6 6 1 0}$ & $\pm \mathbf{0 . 1 1 3 1}$ & $* * *$ & $* * *$ \\
\hline
\end{tabular}

LSD is the least significant difference between the values in the same column.

$* * *$ means $\mathbf{p} \leq \mathbf{0 . 0 1} ; * *$ means $0.01<\mathrm{p} \leq \mathbf{0 . 0 5}$.

Values that are labeled by same letter(a or b)in one column means no significant difference, while are labeled by different letter in same column have significant difference, namely the values labeled by $b$ are significantly lower than the values labeled by a. 

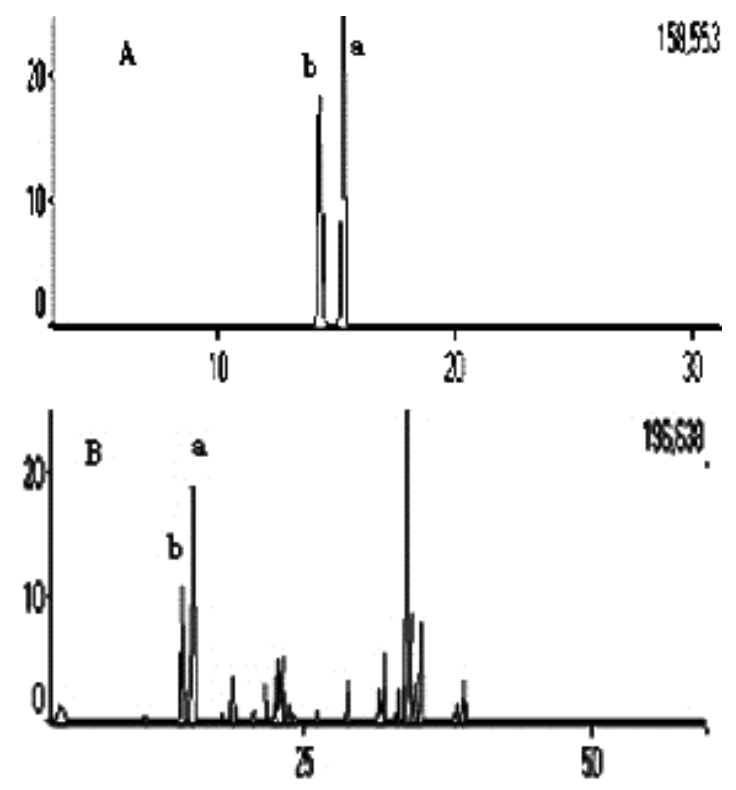

Figure No. 1

The GC chromatograms of standards (A) and sample of Valeriana amurensis (B). a. bornyl acetate; $b$. naphthalene

\section{Seasonal variation of valepotriates and valtrate}

The content of valepotriates began with $21.12 \mathrm{mg} / \mathrm{g}$ in germination period at a higher level, and increased slowly in the next one month. The lowest valepotriates concentration appeared in flowering period at $14.23 \mathrm{mg} / \mathrm{g}$, although, the concentration increased significantly to follow and achieved the highest value, $28.23 \mathrm{mg} / \mathrm{g}$, in fruit ripening period. Thereafter, higher enriched fraction of valepotriates was found in withering period $(20.89 \mathrm{mg} / \mathrm{g}$ ) (Table No. 1). Whereas, Singh et al. (2010) have reported highest valepotriates content in $V$. jatamansi during October-November.

Similarly, the content of valtrate was 0.65 $\mathrm{mg} / \mathrm{g}$ in germination period, which reached higher content in stooling period $(0.80 \mathrm{mg} / \mathrm{g})$. The lowest valtrate concentration appeared in flowering period at $0.31 \mathrm{mg} / \mathrm{g}$ followed by the highest value, $0.87 \mathrm{mg} / \mathrm{g}$, in fruit ripening period (Figure No. 2).

\section{Determination of the best harvest period}

With the growth of plant, dry weight and dry weight ratio per plant increased constantly, and reached the peak in fruit ripening period, withering period separately. The content of the essential oil, bornyl acetate, valepotriates and valtrate increased rapidly from germination period to stooling period, then had a reduction in various degrees in flowering period except for the essential oil. After the transient lower content period, all the active constituents per plant increased nearly twice at least, such as content of the essential oil and bornyl acetate. Among of all active constituents, the content of valtrate changed the most significantly from $0.16 \mathrm{mg}$ to $0.98 \mathrm{mg}$ per plant (Table No. 2). When the plant withered initially, marker compounds except for the essential oil all decreased to a small extent. Fruit ripening period was decided as the best harvest period thought of the content of active constituents and output of drug.

The active constituents in $V$. amurensis can be divided into two groups according to their dynamic rules. the essential oil and bornyl acetate concentrations decreased constantly in all growing periods, while valepotriates, and valtrate concentrations were high and low in different harvest periods. With the growth of plant, active constituents concentrations in regulated weight can be increase commonly when constituents accumulation exceed biomass growth, such as valepotriates, valtrate. On the contrary, the contents of the essential oil and bornyl acetate decreased regularly with expansion of growing periods. Setting the content of five constituents in germination period as $100 \%$, the ratio of the essential oil, bornyl acetate, valepotriates and 
valtrate in germination period and fruit ripening period is $61.52 \%, 68.65 \%, 133.65 \%$ and $133.33 \%$ respectively. The determination of active constituents contents in plant is a very important work to evaluate drug quality and set direction. With the growth of plant, the contents of constituents would change constantly owing to lots of factors but growth cycle is invariant in general. So plants are harvested according to growing periods but not monthly (Bos et al., 1998; Singh et al., 2010). The best harvest period is not only suitable for the drug cultivated in the locality but also provide direction for other region.

Comparing with $V$. officinalis L. s.l. and $V$. jatamansi, there are much more essential oil in $V$. amurensis, so the contents of essential oil, valepotriates and target ingredient bornyl acetate, valtrate were determined during different harvest periods respectively. It is better to determine the content of essential oil and bornyl acetate than either of them only. In order to ascertain the best harvest period of $V$. amurensis, not only the content of active constituents but also the output of drug were investigated. To a certain extent, the best harvest period can be decided directly and more scientific. As a result, fruit ripening period was decided as the best harvest period for the content of active constituents and output of drug. And some other active constituents and what the mechanism generate active constituents would be investigated in the next step.

Table No. 2

Determination of dry weight, dry weight ratio and active constituents in rhizomes and roots of Valeriana amurensis per Plant in different harvest periods

\begin{tabular}{|c|c|c|c|c|c|c|}
\hline Harvest time & $\begin{array}{c}\text { essential oil } \\
(\mu \mathrm{l})\end{array}$ & $\begin{array}{c}\text { bornyl acetate } \\
\text { (mg) }\end{array}$ & $\begin{array}{c}\text { valepotriates } \\
\text { (mg) }\end{array}$ & $\begin{array}{c}\text { valtrate } \\
\text { (mg) }\end{array}$ & $\begin{array}{c}\text { dry weight } \\
\text { (g) }\end{array}$ & $\begin{array}{c}\text { dry weight } \\
\text { ratio } \\
(\%)\end{array}$ \\
\hline Germination period & $6.77^{e}$ & $2.11^{\mathrm{c}}$ & $4.61^{\mathrm{e}}$ & $0.14^{d}$ & $0.22^{\mathrm{e}}$ & $20.55^{d}$ \\
\hline Stooling period & $9.45^{d}$ & $2.74^{b}$ & $9.53^{c}$ & $0.28^{d}$ & $0.35^{d}$ & $19.02^{\mathrm{e}}$ \\
\hline Flowering period & $10.82^{c}$ & $1.42^{d}$ & $7.05^{d}$ & $0.16^{d}$ & $0.50^{c}$ & $21.48^{c}$ \\
\hline Fruit ripening period & $21.58^{b}$ & $2.82^{a}$ & $31.90^{\mathrm{a}}$ & $0.98^{a}$ & $1.13{ }^{a}$ & $24.73^{b}$ \\
\hline Withering period & $22.69^{a}$ & $2.09^{c}$ & $23.00^{b}$ & $0.74^{b}$ & $1.10^{b}$ & $29.02^{\mathrm{a}}$ \\
\hline Variability & $* * *$ & $* * *$ & $* * *$ & $* * *$ & $* * *$ & $* * *$ \\
\hline LSD & $\pm \mathbf{0 . 5 7 5 0}$ & \pm 0.0743 & \pm 0.6825 & \pm 0.0135 & \pm 0.0212 & \pm 0.6448 \\
\hline
\end{tabular}

LSD is the least significant difference between the values in the same column.

$* * *$ means $\mathbf{p} \leq 0.01 ; * *$ means $0.01<p \leq 0.05$.

Values that are labeled by same letter (a or b)in one column means no significant difference, while are labeled by different letter in same column have significant difference, namely the values labeled by $b$ are significantly lower than the values labeled by a. 


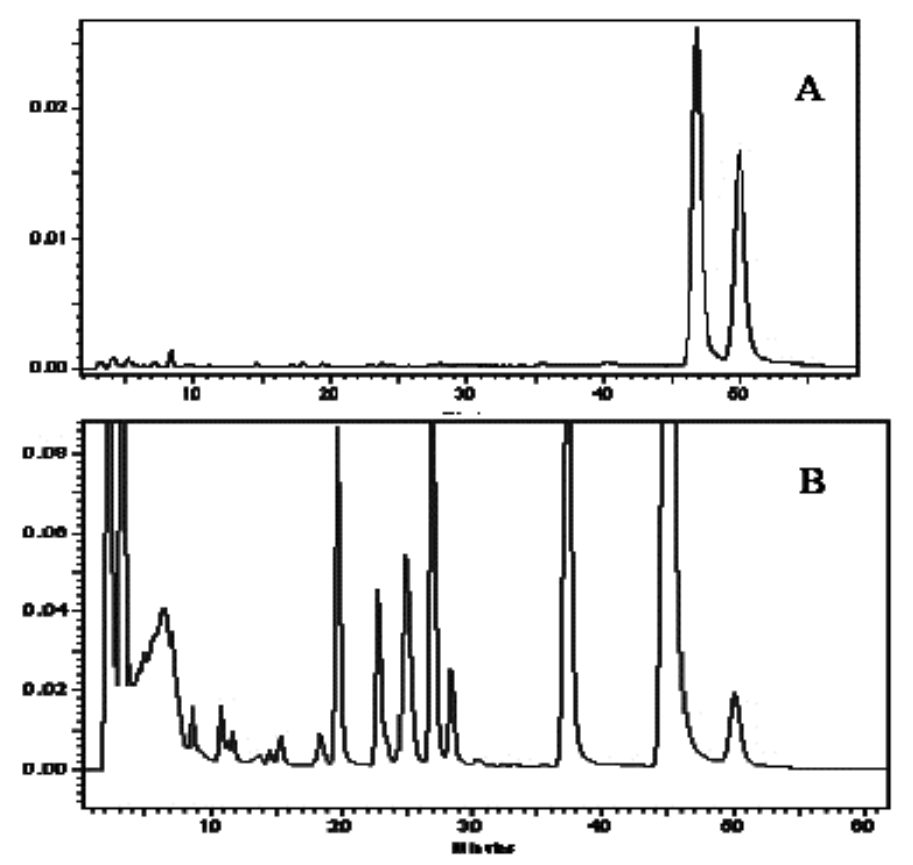

Figure No. 2

The HPLC chromatograms of standard (A) and sample (B) at $255 \mathrm{~nm}$.

A. valtrate; B. sample of Valeriana amurensis

\section{ACKNOWLEDGEMENTS}

This work was supported by grants from the Science Fund for Distinguished Scholars of Heilongjiang Province (No. JC200612), high technology research and development plan of state science ministry (No. 2003AA2Z3523). The authors gratefully acknowledge Professor R. Bos (Department of Pharmaceutical Biology, University Centre for Pharmacy, Groningen Institute for Drug Studies (GIDS), University of Groningen) for providing Mixing standard substances of valtrate and isovaltrate.

\section{REFERENCES}

Bent S, Padula A, Moore D, Patterson M, Mehling W. 2006. Valerian for Sleep: A Systematic Review and Meta-Analysis. Am J Med 119: 1005 - 1012. https://doi.org/10.1016/j.amjmed.2006.02.026

Bos R, Woerdenbag HJ, Hendriks H, Scheffer JJC. 1993. Seasonal variation of the essential oil, valerenic acid derivatives, and valepotriates in Valeriana officinalis roots. Planta Med 59: A698.

https://doi.org/10.1055/s-2006-959991
Bos R, Woerdenbag HJ, Hendriks H, Scheffer JJC. 1997a. Composition of the essential oils from underground parts of Valeriana officinalis L. s.l. and several closely related taxa. Flavour Fragr J 12: 359 - 370. https://doi.org/10.1002/(sici)1099-1026 (199709/10)12:5<359::aid-ffj660>3.0.co;2-g

Bos R, Woerdenbag HJ, Hendriks H, Smit HF, Wikström HV, Scheffer JJC. 1997b. Composition of the essential oil from roots and rhizomes of Valeriana wallichii DC. Flavour Fragr J 12: 123 - 131. https://doi.org/10.1002/(sici)10991026(199703)12:2<123::aid-ffj613>3.0.co;2-4

Bos R, Woerdenbag HJ, Hendriks H, Zwaving JH, De Smet PA, Tittel G, Wikström HV, Scheffer JJC. 1996. Analytical aspects of phytotherapeutic valerian preparations. Phytochem Anal 7: 143 - 151. https://doi.org/10.1002/(sici)10991565(199605)7:3<143::aid-pca284>3.0.co;2-1

Bos R, Woerdenbag HJ, van Putten FMS, Hendriks H, Scheffer JJC. 1998. Seasonal variation of the essential oil, valerenic acid and derivatives, and valepotriates in Valeriana officinalis roots and rhizomes, and the 
selection of plants suitable for phytomedicines. Planta Med 64: 143 - 147. https://doi.org/10.1055/s-2006-957392

Bos R, Herman J, Woerdenbag Pras N. 2002. Determination of valepotriates. $\mathbf{J}$ Chromatogr A 967: 131 - 146. https://doi.org/10.1016/s0021-9673(02)00036-5

Cecilia MM, Fernandez SP, Loscalzo LM, Wasowski C, Paladini AC, Marder M, Medina JH, Viola H. 2009. Hesperidin, a flavonoid glycoside with sedative effect, decreases brain pERK1/2 levels in mice. Pharmacol Biochem Behav 92: 291 - 296. https://doi.org/10.1016/j.pbb.2008.12.016

Fuzzati N, Wolfender JL, Hostettmann K, Msonthi JD, Mavi S, Molleyres LP. 1996. Isolation of antifungal valepotriates from Valeriana capense and the search for valepotriates in crude Valerianaceae extracts. Phytochem Anal 7: 76 - 85 .

https://doi.org/10.1002/(sici)1099. 1565(199603)7:2<76::aid-pca288>3.0.co;2-I

Gao XQ, Björk L. 2000. Valerenic acid derivatives and valepotriates among individuals, varieties and species of Valeriana. Fitoterapia 71: 19 $-24$. https://doi.org/10.1016/s0367-326x(99)00094-5

Gränicher F, Christen P, Kapetanidis I. 1995. Essential oils from normal and hairy roots of Valeriana officinalis var sambucifolia. Phytochem 40: 1421 - 1424. https://doi.org/10.1016/0031-9422(95)00492-p

Huo JH, Du XW, Sun H, Chen XY. 2007. Determination of bornyl acetate in Valeriana amurensis volatile oil by Gas chromatography. Lishizhen Medicine and Materia Medica Research 18: 2381 - 2382.

Javidnia K, Miri R, Kamalinejad M, Khazraii H. 2010. Chemical composition of the volatile oil of aerial parts of Valeriana sisymbriffolia Vahl. grown in Iran. Flavour Fragr J 21: 516 - 518. https://doi.org/10.1002/ffj.1660

Kovacevic N, Pavlovic M, Menkovic N, Tzakou O, Couladis M. 2002. Composition of the essential oil from roots and rhizomes of Valeriana pancicii Halácsy \& Bald. Flavour Fragr J 17: 355 - 357. https://doi.org/10.1002/ffj.1100

Marder M, Viola H, Wasowski C, Fernández S, Medina JH, Paladini AC. 2003. 6-
Methylapigenin and hesperidin: new valeriana flavonoids with activity on the CNS. Pharmacol Biochem Behav 75: 537 545. https://doi.org/10.1016/s0091-3057(03)00121-7

Novak J, Novak S, Bitsch C, Franz CM. 2000. Essential oil composition of underground parts of Valeriana celtica ssp. from Austria and Italy. Flavour Fragr J 15: 40 - 42. https://doi.org/10.1002/(sici)10991026(200001/02)15:1<40::aid-ffj863>3.0.co;2-b

Penzkofer M, Baron A, Naumann A, Krähmer A, Schulz H, Heuberger H. 2018. Characterization of essential oil distribution in the root cross-section of Valeriana officinalis L. s.l. by using histological imaging techniques. Plant Methods 14: 41. https://doi.org/10.1186/s13007-018-0309-4

Safaralie A, Fatemi S, Sefidkon F. 2008. Essential oil composition of Valeriana officinalis L. roots cultivated in Iran. Comparative analysis between supercritical $\mathrm{CO}_{2}$ extraction and hydrodistillation. J Chromatogr A 1180: $159-164$.

https://doi.org/10.1016/j.chroma.2007.12.011

Sati S, Mathela CS. 2005. Essential oil composition of Valeriana hardwickii var. arnottiana from the Himalayas. Flavour Fragr J 20: 299 301.

https://doi.org/10.1002/ffj.1415

Schumacher B, Scholle S, Hölzl J, Khudeir N, Hess S, Müller CE. 2002. Lignans isolated from valerian: identification and characterization of a new olivil derivative with partial agonistic activity at A1 adenosine receptors. J Nat Prod 65: 1479 - 1485. https://doi.org/10.1021/np010464q

Shohet D, Wills RB, Stuart DL. 2001. Valepotriates and valerenic acids in commercial preparations of valerian available in Australia. Pharmazie 56: 860 - 863.

Singh RD, Gopichand, Meena RL, Sharma B, Singh B, Kaul VK, Ahuja PS. 2010. Seasonal variation of bioactive components in Valeriana jatamansi from Himachal Pradesh, India. Ind Crops Prod 32: 292 - 296. https://doi.org/10.1016/j.indcrop.2010.05.006

Stoll A, Seebeck E. 1957. Mitteilung über Valeriana. Die Isolierung von Hesperitinsäure, Behensäure und von Zwei Unbekannten Säuren aus Baldrian. Liebigs Ann Chem 
603: $158-168$.

https://doi.org/10.1002/jlac.19576030117

Taibi DM, Landis CA, Petry H, Vitiello MV. 2007. A systematic review of valerian as a sleep aid: safe but not effective. Sleep Med Rev 11: $209-230$. https://doi.org/10.1016/j.smrv.2007.03.002

Thies PW. 1966. Zur Konstitution der isovaleriansaureester Valepotriat, Acetoxyvalepotriat und Dihydrovalepotriat. Tetrahedron Lett 11: 1163 - 1170. 